\title{
Immunohistochemical Localization of Apolipoprotein E in Human Glial Neoplasms
}

\author{
Masaji Murakami," Yukitaka Ushio," Yoshimasa Morino," Takao Ohta,' and Yasuhiko Matsukado* \\ Departments of Neurosurgery, ${ }^{*}$ Biochemistry, ${ }^{\ddagger}$ Pediatrics, ${ }^{\S}$ Kumamoto University Medical School, Honjo, 1-1-1, Kumamoto 860, Japan
}

\begin{abstract}
Immunocytochemical analyses revealed the presence and distribution of apolipoprotein $\mathbf{E}$ (apo $\mathbf{E}$ ) in normal human brain tissue as well as in $\mathbf{7 7}$ human intracranial neoplasms. In normal brain tissues, the perikarya of astrocytes exhibited a strong positive reaction, whereas the Bergmann glia were stained to a moderate degree. However, no immunoreactivity was observed with neurons, oligodendrocytes, ependymal cells, and choroidal epithelium. Among the intracranial neoplasms, oligodendroglioma, choroid plexus papilloma, hemangioblastoma, primary malignant lymphoma, neurinoma, meningioma, pituitary adenoma, and craniopharyngioma were all negative. Immunoreactivity in the peripheral neuroblastoma was nil. However, the perikarya of astrocytomas and glioblastomas showed a positive reaction. Analyses on the degree of anaplasia and the amount of apo-E as an intensity of immunostaining showed a negative correlation. The astrocytic elements were stained in mixed oligoastrocytomas and medulloblastomas with glial differentiation. A few cases of ependymomas showed weak perikaryal immunostaining. Western blot analyses with anti-apo $E$ antibody of a freshly prepared surgical specimen with astrocytomas revealed a single band with a molecular weight of $\sim 37,000$. The well differentiated cultured human astrocytoma cells secreted apo $\mathbf{E}$ into the medium. These lines of evidence suggest that apo $\mathbf{E}$ may serve as a potential marker specific for astrocytomas and glioblastomas, as well as an indicator of astrocytic tumor cell differentiation. The apo $\mathrm{E}$ localization in human brain tumors could be clinically relevant and diagnostically useful.
\end{abstract}

\section{Introduction}

Apo $\mathrm{E}$ is a $34,000 \mathrm{D}$ lipophilic protein of known sequence (1), circulating in plasma as a constituent of lipoproteins such as chylomicrons, VLDL, and HDL. In the plasma it plays a key role in determining the uptake of these same lipoproteins by tissues $(2,3)$. The recognition of apo $\mathrm{E}$ is mediated by two different receptor systems; one is the apo $B, E$ receptor present on both hepatic and extrahepatic cells $(2,4)$, and the other is the apo $\mathrm{E}$ receptor in the liver $(5,6)$. It is generally accepted that apo $\mathrm{E}$ is mainly synthesized by the liver (7). However, other tissues such as human kidney and adrenal glands also synthesize the protein (8). A recent report by Elshourbagy et al.

Address all correspondence to Dr. Masaji Murakami, Department of Neurosurgery, Kumamoto University Medical School, Honjo 1-1-1, Kumamoto 860, Japan.

Received for publication 27 February 1987 and in revised form 19 January 1988.

J. Clin. Invest.

(c) The American Society for Clinical Investigation, Inc.

$0021-9738 / 88 / 07 / 0177 / 12 \$ 2.00$

Volume 82 , July $1988,177-188$ extended this notion. They found apo E mRNA to be abundant in the liver, and they also detected it in many other tissues in relatively high concentrations (9). Among these tissues was the brain.

Two lines of evidence suggested the potential importance of apo $E$ in the central nervous system. In the cerebrospinal fluid of normal humans, apo $\mathrm{E}$ is present at a higher concentration (3-5\% of plasma concentration) than would be expected for a filtered plasma protein (10). Furthermore, apo E mRNA is also abundant in the human brain (9). As a first step in elucidating the underlying mechanism and implications of this finding, Boyles et al. obtained evidence for the presence of abundant amounts of apo $\mathrm{E}$ within astrocytes of the rat brain, by using immunocytochemical techniques (11). The finding that apo $\mathrm{E}$ is synthesized by a human neurofibrosarcoma-derived cell culture but not by benign neurofibromas has also been reported (12). These findings suggested to us the potential value of apo $E$, together with the general morphology of neoplastic cells, for the identification and staging of glial neoplasms of the central nervous system. In this report, we have examined the immunocytochemical distribution of apo $\mathrm{E}$ in both the normal human brain and the primary human brain tumors. We found that in the normal human brain, astrocytes have abundant immunoreactivity for apo E. Among brain tumors, all kinds of astrocytomas and glioblastomas exhibited an immunoreaction for apo E. A negative correlation was observed between the intensity of immunoreactivity and the degree of anaplasia. In addition, in vitro experiments using cultured astrocytoma cells demonstrated the secretion of apo $\mathrm{E}$ by these cells, and a negative correlation between the secretion of apo $E$ and the degree of dedifferentiation of these neoplastic cells. Thus, apo E may potentially serve as a specific marker for astrocytomas and glioblastomas, as well as an indicator of astrocytic tumor cell differentiation.

\section{Methods}

Preparation of affinity-purified apo E specific IgG. Human apo E was isolated from pooled serum from normolipidemic volunteers by conventional methods (13-15). The purity of the apo $\mathrm{E}$ was evaluated by isoelectric focusing and SDS-PAGE. Two New Zealand White rabbits (2.0-2.5 kg) were immunized with $0.5 \mathrm{mg}$ of purified apo E, as described $(16,17)$. Upon double immunodiffusion analysis, the antiserum formed a single precipitin line with apo $\mathrm{E}$, whereas no reaction was observed with other apolipoproteins or with HSA.

Purified apo E (10 mg) was coupled to $5 \mathrm{ml}$ of $\mathrm{CNBr}$-activated Sepharose 4B gel, as described (18). $90 \mathrm{ml}$ of anti-apo E serum was applied to a column of apo E Sepharose $4 B(1.0 \times 7.0 \mathrm{~cm})$ equilibrated with $0.1 \mathrm{M}$ borate, $1.0 \mathrm{M} \mathrm{NaCl}$, and $0.1 \%$ Tween 20 (pH 8.0). After the column was washed extensively with the same buffer, it was eluted with $0.2 \mathrm{M}$ glycine- $\mathrm{HCl}$ buffer ( $\mathrm{pH} 2.2$ ). The effluent fractions were rapidly neutralized to $\mathrm{pH} 7.4$ and concentrated to $3.0 \mathrm{mg} / \mathrm{ml}$. Thus, affinity-

1. Abbreviations used in this paper: buffer $\mathrm{B}, 50 \mathrm{mM}$ Tris and $0.15 \mathrm{M}$ $\mathrm{NaCl}$ (pH 10); db, dibutyryl; GFAP, glial fabrillary acidic protein; HRP, horseradish peroxidase. 
purified apo E-specific IgG (monospecific anti-human apo $\mathrm{E}$ antibody) was obtained.

Preparation of Fab'-horseradish peroxidase $(H R P)^{l}$ conjugates. Fab' antibody to apo $E$ was conjugated with HRP (type 4, RZ = 3.0, Sigma Chemical Co., St. Louis, MO) by the maleimide method, as described $(19,20)$. In brief, the $F\left(a^{\prime}\right)_{2}$ fragment was prepared from the IgG by digestion with pepsin (Sigma Chemical Co.) at pH 3.9 for $8 \mathrm{~h}$ at $37^{\circ} \mathrm{C}$, which was followed by $40 \%$ ammonium sulfate fractionation and by Sephadex G-150 column chromatography. To prepare the Fab' fragment, $500 \mu \mathrm{l}$ of $2 \mathrm{mg} / \mathrm{ml}$ of $\mathrm{F}\left(\mathrm{ab}^{\prime}\right)_{2}$ fragment was reduced with 10 mM 2-mercaptoethylamine (Sigma Chemical Co.) in $0.1 \mathrm{M}$ sodium phosphate buffer at $\mathrm{pH} 6.0$ for $90 \mathrm{~min}$ at $37^{\circ} \mathrm{C}$. The reactant was applied to a Sephadex G-25 column to remove the remaining 2-mercaptoethylamine. On the other hand, $6 \mathrm{mg}$ of HRP in $1.0 \mathrm{ml}$ of $0.1 \mathrm{M}$ sodium phosphate buffer, $\mathrm{pH} 7.0$, was incubated with $2.4 \mathrm{mg}$ of $N$-hydrosuccinimide of $\mathrm{N}$-(4-carboxycyclohexylmethyl) maleimide (Zieben Chemicals, Tokyo, Japan) in $100 \mu l$ of $N$ - $N^{\prime}$-dimethylformamide for 20 min at $30^{\circ} \mathrm{C}$. After centrifugation, the supernatant was applied to a Sephadex G-25 column equilibrated with $0.1 \mathrm{M}$ sodium phosphate buffer at pH 6.0. Next, HRP and Fab' fragments thus obtained were mixed on an equimolar basis (20-80 $\mu \mathrm{M})$ and incubated for $1 \mathrm{~h}$ at $37^{\circ} \mathrm{C}$ or overnight at $4^{\circ} \mathrm{C}$, after which they were applied to an Ultrogel AcA 44 column (LKB Instrument Co., Villeneuve-La-Garenne, France) chromatography with $0.1 \mathrm{M}$ sodium phosphate buffer at $\mathrm{pH}$ 6.5. Fractions containing monomeric conjugates composed of equimolar amounts of HRP and Fab' were used for the procedures.

The ELISA procedure. Monospecific anti-apo $\mathrm{E}$ antibody (affinity-purified apo E-specific IgG) prepared as above was absorbed to the well of polystyrene microtiter plates (Falcon 3911, Micro Test 111 flexible assay plate). Each well containing $1 \mu \mathrm{g}$ of $\mathrm{IgG}$ in $0.1 \mathrm{ml}$ of 0.1 $M$ sodium carbonate buffer ( $\mathrm{pH} \mathrm{8.3)}$ was incubated at $4^{\circ} \mathrm{C}$ for $16 \mathrm{~h}$ in a humid chamber, and the unabsorbed IgG solution was aspirated from the wells. After each well was washed three times with $0.5 \mathrm{ml}$ of $0.15 \mathrm{M}$ $\mathrm{NaCl}$ ( $\mathrm{pH} 7.4$ ) (buffer A), each one was incubated for $2 \mathrm{~h}$ at $37^{\circ} \mathrm{C}$ with $300 \mu \mathrm{l}$ of $1 \%$ BSA (fraction 5; Nakarai, Kyoto, Japan) in $10 \mathrm{mM}$ sodium phosphate buffer ( $\mathrm{pH} 7.4$ ) containing $0.15 \mathrm{M} \mathrm{NaCl}$ to avoid nonspecific binding of the proteins to the wells. The wells were then washed with $0.5 \mathrm{ml}$ of $0.15 \mathrm{M} \mathrm{NaCl}(\mathrm{pH} \mathrm{7.4)}$ and incubated overnight at $4^{\circ} \mathrm{C}$ with $100 \mu \mathrm{l}$ of samples. After aspiration of the sample solution and washing in the same manner as described above, $100 \mu \mathrm{l}$ of peroxidase-labeled $\mathrm{Fab}^{\prime}(1 \mu \mathrm{g} / \mathrm{ml})$ was added to each well. Incubation was carried out for $2 \mathrm{~h}$ at $37^{\circ} \mathrm{C}$ and the wells were aspirated and washed four times, in the same manner. The enzymatic color reaction was developed, using (2,2'Azino-bis [3-ethyl-benzothiazoline-6-sulfonic Acid]) as a substrate. The optical density was read at $405 \mathrm{~nm}$ on a micro titer plate reader (MR580; Dynatech Laboratories, Inc., Alexandria, VA). The resulting standard curve was sigmoid-shaped on semilog paper with an approximately linear central part. Accurate quantitative results could be obtained for samples containing between 0.1 and $70 \mathrm{ng}$ apo $\mathrm{E} / \mathrm{ml}$.

Characterization of apo $E$ in astrocytoma tissues. Proteins were extracted from homogenized astrocytoma tissues of a surgical specimen in detergent-containing buffer $(0.5 \%$ Nonidet-P40, $0.15 \mathrm{M} \mathrm{NaCl}$, and $50 \mathrm{mM}$ Tris $/ \mathrm{HCl}, \mathrm{pH} 8.5$ ), and then centrifuged at $100,000 \mathrm{~g}$ for 1 $h$ at $4^{\circ} \mathrm{C}$. The supernatant was recovered and a portion was run on the $15 \%$ SDS-PAGE. Next, the proteins were electrophoretically transferred from the gel to a nitrocellulose paper at a constant current of 160 $\mathrm{mA}$ for $2 \mathrm{~h}$ at room temperature, using a semi-dry Electroblotter (SM 17556; Sartorius Filters, Inc., Hayward, CA) (21). After the blots had been blocked with $50 \mathrm{mM}$ Tris and $0.15 \mathrm{M} \mathrm{NaCl}$ (pH 10) (buffer B), which contained $3 \% \mathrm{BSA}$, for $30 \mathrm{~min}$ at room temperature, they were incubated overnight at $4^{\circ} \mathrm{C}$ with a $1: 1,000$ dilution of rabbit monospecific anti-human apo $\mathrm{E}$ antibody in buffer B containing 3\% BSA (pH 10). The blots were then washed three times with buffer $B$ and reacted for $1 \mathrm{~h}$ at room temperature with peroxidase-labeled goat anti-rabbit IgG (Tago, Inc., Burlingame, CA) at 1:1,000. The blots were washed three times with the same buffer, and incubated for 3-5 min with diaminobenzidine $(0.2 \mathrm{mg} / \mathrm{ml})$ (Sigma Chemical Co.) in $50 \mathrm{mM}$ so- dium phosphate buffer ( $\mathrm{pH}$ 6.0) in the presence of $0.01 \mathrm{M} \mathrm{H}_{2} \mathrm{O}_{2}$ to visualize the immunoreactive band.

Immunocytochemical study. A sample of human brain tissue of a 34-yr-old male was used as a normal control. He had been autopsied 6 $\mathrm{h}$ after death due to pneumonia. Consent for the sample collection was obtained from his family. Human brain tumors were obtained at the time of surgical procedures and were fixed in $10 \%$ formaldehyde solution for $2 \mathrm{~d}$, embedded in paraffin, and sectioned into a width of 4-5 $\mu \mathrm{m}$. Freshly prepared sections were deparaffinized and placed in a blocking solution of $3 \% \mathrm{H}_{2} \mathrm{O}_{2}$ for $30 \mathrm{~min}$ and then in another blocking solution of normal goat serum for $30 \mathrm{~min}$, followed by incubation overnight at $4^{\circ} \mathrm{C}$ with primary antibodies, diluted in 3\% BSA in PBS. The primary antibodies were rabbit affinity-purified apo E-specific IgG at 1:3,000, rabbit IgG against glial fibrillary acidic protein (GFAP) (DAKO, Santa Barbara, CA) at 1:2,000, or nonimmune sera at 1:500. The slides were washed extensively with PBS and then incubated in a second antibody (affinity-purified biotinylated goat anti-rabbit IgG) for $\mathbf{4 0 ~} \mathrm{min}$ at room temperature according to the recommended dilution. Then they were washed extensively and incubated for $30 \mathrm{~min}$ in an avidin-biotin complex (ABC Kit; Vector Laboratories, Inc., Burlingame, CA) at room temperature. To detect the presence of peroxidase, the sections were incubated for $5-10 \mathrm{~min}$ at room temperature with 0.2 $\mathrm{mg} / \mathrm{ml}$ of diaminobenzidine in $50 \mathrm{mM}$ Tris- $\mathrm{HCl}$ buffer $(\mathrm{pH} 7.2)$ in the presence of $0.01 \mathrm{M} \mathrm{H}_{2} \mathrm{O}_{2}$, and then washed. Nuclei were counterstained with hematoxylin. Interference was never observed even when using normal goat serum as a blocking solution. To establish specificity of the immunocytochemical reaction, each reagent used was omitted in turn. Controls using nonimmune rabbit sera showed a negative staining.

Human glioma culture. Two types of human glioma cells used in these experiments were prepared in the following manner; freshly resected astrocytoma (Gr-2) or glioblastoma tissues obtained during surgical procedures were minced into a fine pulp and placed in $0.25 \%$ trypsin/ $/ 0.02 \%$ EDTA solution for 30 min with mixing at $37^{\circ} \mathrm{C}$ in $5 \%$ $\mathrm{CO}_{2}$ incubator. The cells were centrifuged at $120 \mathrm{~g}$ for $3 \mathrm{~min}$, and the pellets were resuspended in fresh medium and used for culture in RPMI 1640 medium (Nissui Pharmaceutical Co., Tokyo) containing 10\% FCS (Biocell Laboratories, MD). Thus, the primary culture of astrocytoma served for the experiments. The glioblastoma cell line (KMG-5) that was used was established in our laboratory (22). The glioma cells were plated to 24-well $(16 \times 16 \mathrm{~mm})$ polystyrene dishes. Each well had $1.0 \times 10^{5}$ cells in $1 \mathrm{ml}$ of culture medium. After the medium was preincubated in the absence or presence of $10 \mu \mathrm{g} / \mathrm{ml}$ $\beta$-methasone, dibutyryl-cAMP (db-cAMP) (1 mM) (Sigma Chemical Co.) or $100 \mu \mathrm{g} / \mathrm{ml} \mathrm{LDL}$, which was isolated by sequential ultracentrifugation of human plasma $(d, 1.019-1.063)$ for $24 \mathrm{~h}$, it was replaced. The amounts of apo $\mathrm{E}$ secreted into the culture medium were determined over 72 h using ELISA.

\section{Results}

Identification and characterization of apo $E$ in astrocytoma tissues. To examine the property of apo $\mathrm{E}$ found in human astrocytoma obtained at the time of surgical procedures, tumor tissue was extracted and analyzed by gel electrophoresis, followed by immunoblot, as described in Methods. Using a monospecific anti-apo $\mathrm{E}$ antibody, an immunoblot of tissue extracts of low grade astrocytoma revealed a single band with a molecular weight of $\sim 37,000 \mathrm{D}$, an apparently higher molecular mass than that of human plasma apo E (Fig. 1).

Immunocytochemical demonstration of apo $E$ in normal human brain. The sections of formaldehyde-fixed normal human brain were examined by light microscopy for the presence of immunoreactive apo $\mathrm{E}$. In all of the major subdivisions, such as cerebrum, cerebellum, pons, medulla, and spinal cord, astrocytes were intensely immunoreactive for apo $\mathrm{E}$ from both surgical and autopsy specimens (Fig. 2). Astrocytes were 


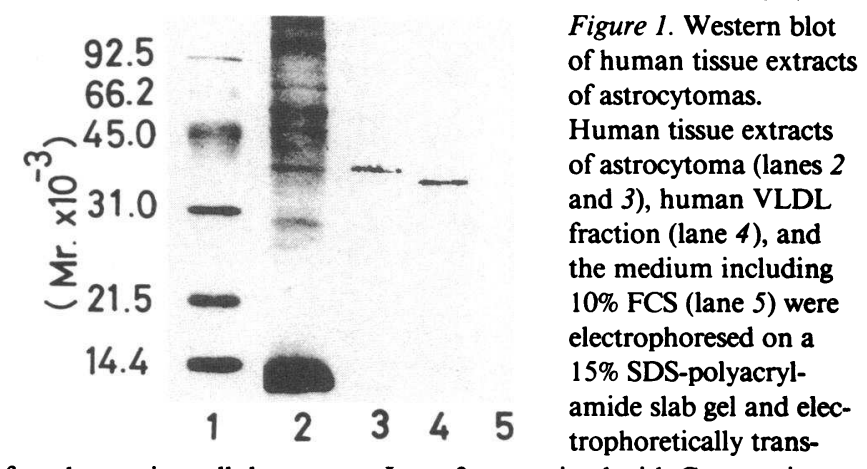

ferred to a nitrocellulose paper. Lane 2 was stained with Coomassie Blue and lanes 3-5 were stained with monospecific anti-human apo E antibody. A single band of $\sim 34,000 \mathrm{D}$ is seen in lane 4, and a single band of $\sim 37,000 \mathrm{D}$ is seen in lane 3 . Lane 5 shows no specific band. Lane 1 shows the low molecular weight marker.

identified by conventional morphology and GFAP immunoreactivity. Immunoreactive apo $\mathrm{E}$ was predominant around the nucleus of most astrocytes, although some of their processes were stained for apo E. Astrocytic processes that end on basement membranes along the blood vessels were visualized by the reaction product for apo $\mathrm{E}$. The reaction product for apo $\mathrm{E}$ was almost of equal intensity for both protoplasmic astrocytes of the gray matter and fibrous astrocytes of the white matter (data not shown). Small blood vessels were not reactive for apo E (Fig. 2), although some large blood vessels were lined by the reaction product for apo $\mathrm{E}$ (data not shown). Neither neurons nor satellite oligodendrocytes were reactive for apo $E$ (Fig. 2). Bergmann glia (Fig. 3) and pituicytes (Fig. 4), cells that have characteristics in common with astrocytes $(23,24)$ also displayed the apo $\mathrm{E}$ reaction product. Giant apo $\mathrm{E}$ unreactive Purkinje cells were surrounded by smaller Bergmann glia, the perikarya of which were reactive for apo E. Unlike the case of

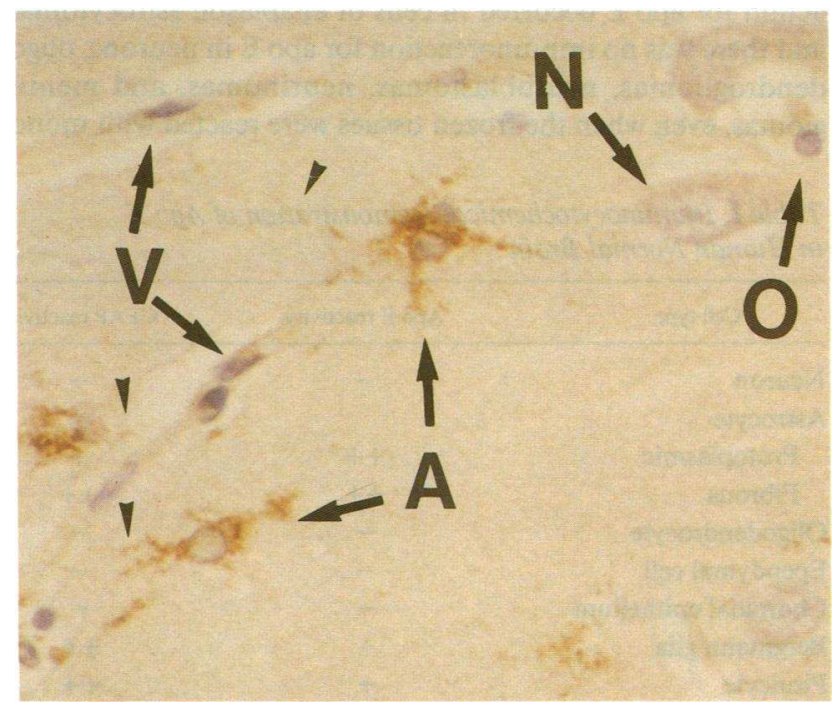

Figure 2. Apo E localization in the normal human cerebral cortex $(\times 330)$. Immunoreactive apo $\mathrm{E}$ is predominantly seen around the nucleus of astrocytes $(A)$, although some of their processes are stained for apo E. The stained astrocytic processes (arrowheads) are seen ending on small blood vessels $(V)$, which are not reactive for apo E. Neither neurons $(N)$ nor satellite oligodendrocytes $(O)$ are reactive. Light counterstain with hematoxylin was used.
GFAP, reactive cell processes of the Bergmann glia that transversed the molecular layer and lined the surface of the cerebellum were absent (Fig. 3). Neither ependymal cells nor choroidal epithelium were reactive for apo E. Parallel experiments revealed that GFAP is found in the perikarya and processes of astrocytes, Bergmann glia and pituicytes, but not in other nervous tissues. This was identical with data in the literature (Table I) $(23,25,26)$.

Immunocytochemical demonstration of apo $E$ in human brain tumors. On examination of 18 subtypes of astrocytomas, all showed perikaryal immunoreaction for apo $\mathrm{E}$. In pilocytic astrocytomas, most of the cells were strongly accentuated by immunostaining. Approximately $80 \%$ of the cells among the protoplasmic (low grade) astrocytomas showed abundant staining, and the remaining ones showed a weak but significant immunoreaction (Fig. 5). Parallel experiments in the same fields revealed abundant immunoreactivity for GFAP in the perikarya and processes of most neoplastic astrocytes in low grade astrocytomas. This also was identical with data in the literature $(23,27)$. On examination of anaplastic (high grade) astrocytomas, a moderate degree of immunoreaction for apo $\mathrm{E}$ was observed in only a few cells, while a large number of the cells was intensely stained for GFAP. No immunoreaction for apo $\mathrm{E}$ was observed in some areas where a strong immunoreaction for GFAP was seen (Fig. 6). Correlations between tumor grading and apo E or GFAP immunoreactivity in 18 astrocytomas are summarized in Table II. The negative correlation was greater in the case of apo $\mathrm{E}$ immunoreactivity than in GFAP. All cases of nine glioblastomas examined also showed perikaryal immunoreaction for apo E. Varying apo E immunoreactivities were seen as follows. In one case (case 1) (Fig. 7), cells with a gemistocytic or bizarre form were moderately to intensely stained. The cells of large and multinucleated forms were weakly stained. Small, round components showed little or no staining. The area of necrosis remained unstained. In parallel experiments, a higher GFAP immunoreactivity was detected, especially in the perivascular areas, in comparison with apo E contents. Another case (case 2) (Fig. 7) likewise showed that only a few neoplastic cells showed a weak immunoreaction for apo $\mathrm{E}$, whereas a large number of the cells revealed GFAP immunoreaction to a moderate degree, especially in the perivascular areas. Some reactive astrocytes admixed with neoplastic cells were intensely stained (data not shown).

To determine whether the apo $\mathrm{E}$ reactive cells were neoplastic ones or invaded macrophages, human macrophage-specific antibody (28) was used for cell identification in case 2 of glioblastoma. This case was chosen for study because some of the apo E-reactive cells seemed to have a foamy appearance and the small dark nuclei typical of macrophages. None of the cells were stained positively (Fig. 7).

On examination of 10 ependymomas, only two showed apo $\mathrm{E}$ immunoreactive material, and here, $\sim 10 \%$ of the cells showed weak perikaryal staining for apo E. In contrast, all exhibited strong perikaryal immunoreaction for GFAP. In seven, $>70 \%$ of the cells revealed strong GFAP immunoreactivity, and in the remaining three, 10-20\% of the cells showed strong immunoreaction for GFAP (Fig. 8).

On examination of three oligodendrogliomas, no apo $\mathrm{E}$ positive tumor cells were evident, whereas GFAP positive tumor cells, which amounted to $\sim 40 \%$ of the tumor cells, were present in all three cases (Fig. 9). In cases of mixed oli- 

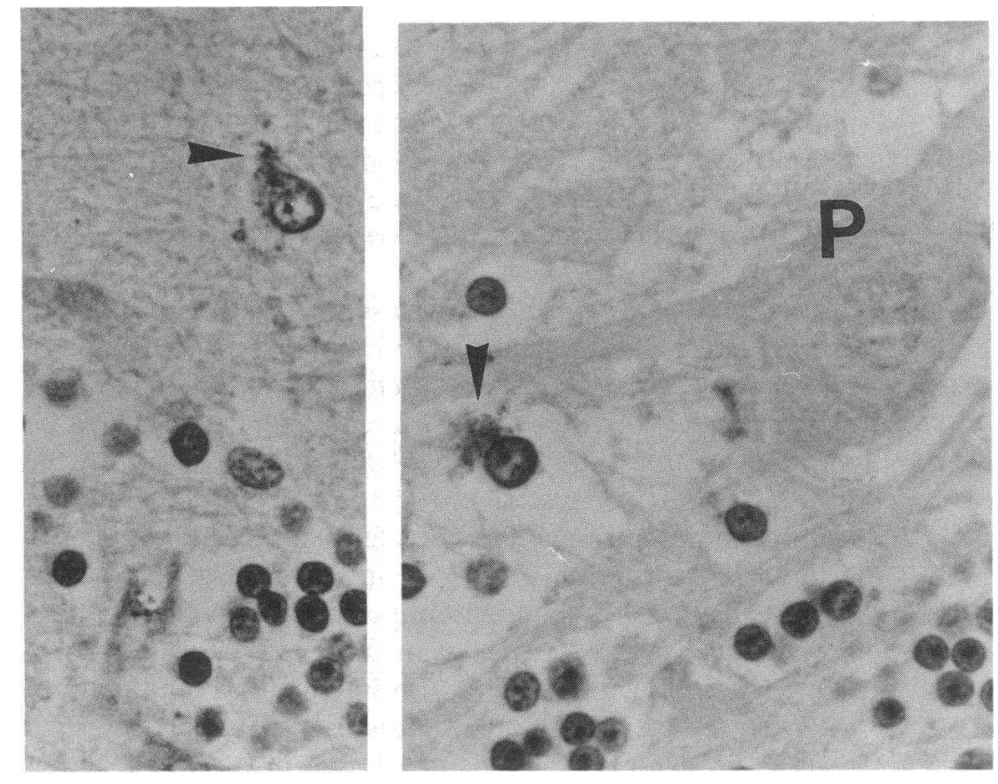

Figure 3. Apo E localization in human cerebellum (dark reaction product $)(\times 800)$. Giant unreactive Purkinje cells for apo $\mathrm{E}(P)$ are surrounded by smaller Bergmann glia, the perikarya of which is rective for apo $\mathrm{E}$ (arrowheads). The processes of Bergmann glia are not rich in immunoreactive apo E. Light counterstain with hematoxylin was used. goastrocytomas, morphologically identifiable astrocytic components were intensely reactive for apo $\mathrm{E}$.

On examination of 12 medulloblastomas, only three exhibited immunoreactivity for apo E. In one, the surgical specimen revealed a highly cellular tumor composed of small, round to polygonal cells with hematoxyphilic nuclei and no special arrangement. No distinct processes were recognized in these cells. Mitotic figures were frequently observed. Strong positive staining for apo $\mathrm{E}$ was observed in a few of these cells, which formed small clusters. The perikarya and polar processes as well were intensely stained for apo E. In parallel experiments, the case described above exhibited a strong positive reaction for GFAP in the perikarya of the cells, and in serial sections simultaneously exhibited apo $\mathrm{E}$ immunoreaction in the same fields (Fig. 10). The difference of immunostaining patterns between apo $\mathrm{E}$ and GFAP is unknown. In another two apo $\mathrm{E}$ positive cases, one of which demonstrated the coexistence of apo E and GFAP, abundant immunoreactive materials were

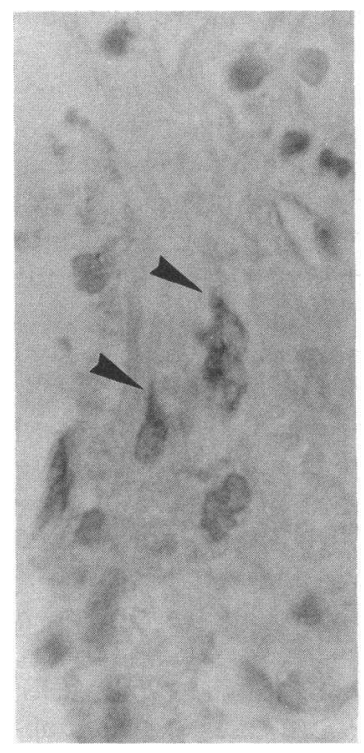

Figure 4. Apo E localization in human pituitary gland (dark reaction product $)(\times 300)$. Fine and thin staining is seen in the perikarya of the pituicytes (arrowheads). Light counterstain with hematoxylin was used. observed in the perikarya of only a few neoplastic cells. Morphologically, the positive cells were neoplastic cells, not reactive astrocytes, and were similar in shape and size to the coexisting unstained cells.

No immunoreaction for apo $\mathrm{E}$ was seen in other intracranial neoplasms such as choroid plexus papillomas, hemangioblastomas, primary malignant lymphomas, neurinomas, meningiomas, pituitary adenomas, and craniopharyngiomas (Table III). Peripheral neuroblastomas also showed no immunoreaction for apo E (Fig. 11). In parallel experiments using paraformaldehyde-fixed frozen sections of the human normal brain or of brain tumors, immunocytochemical demonstration revealed evidence identical with that obtained in the paraffin-embedded sections. That is, a weakly positive immunoreaction for apo $\mathrm{E}$ occurred in cells of anaplastic astrocytomas, and there was no immunoreaction for apo $E$ in neurons, oligodendrogliomas, neuroblastomas, neurinomas, and meningiomas, even when the frozen tissues were reacted with mono-

Table I. Immunocytochemical Demonstration of Apo E in Human Normal Brain

\begin{tabular}{lcc}
\hline \multicolumn{1}{c}{ Cell type } & Apo E reactivity & GFAP reactivity \\
\hline Neuron & - & - \\
Astrocyte & & \\
$\quad$ Protoplasmic & ++ & + \\
$\quad$ Fibrous & ++ & ++ \\
Oligodendrocyte & - & - \\
Ependymal cell & - & - \\
Choroidal epithelium & - & - \\
Bergmann glia & + & ++ \\
Pituicyte & + & ++ \\
Tanycyte & ND & ND \\
& & \\
\hline
\end{tabular}

Strong positive immunoreaction for apo $\mathrm{E}$ was seen in astrocytes. Bergmann glia and pituicytes also exhibited a positive reaction for apo E. No immunoreaction was observed with neurons, oligodendrocytes, ependymal cells, and choroidal epithelium. Immunoreactive intensity is expressed as,+++ , or - . 

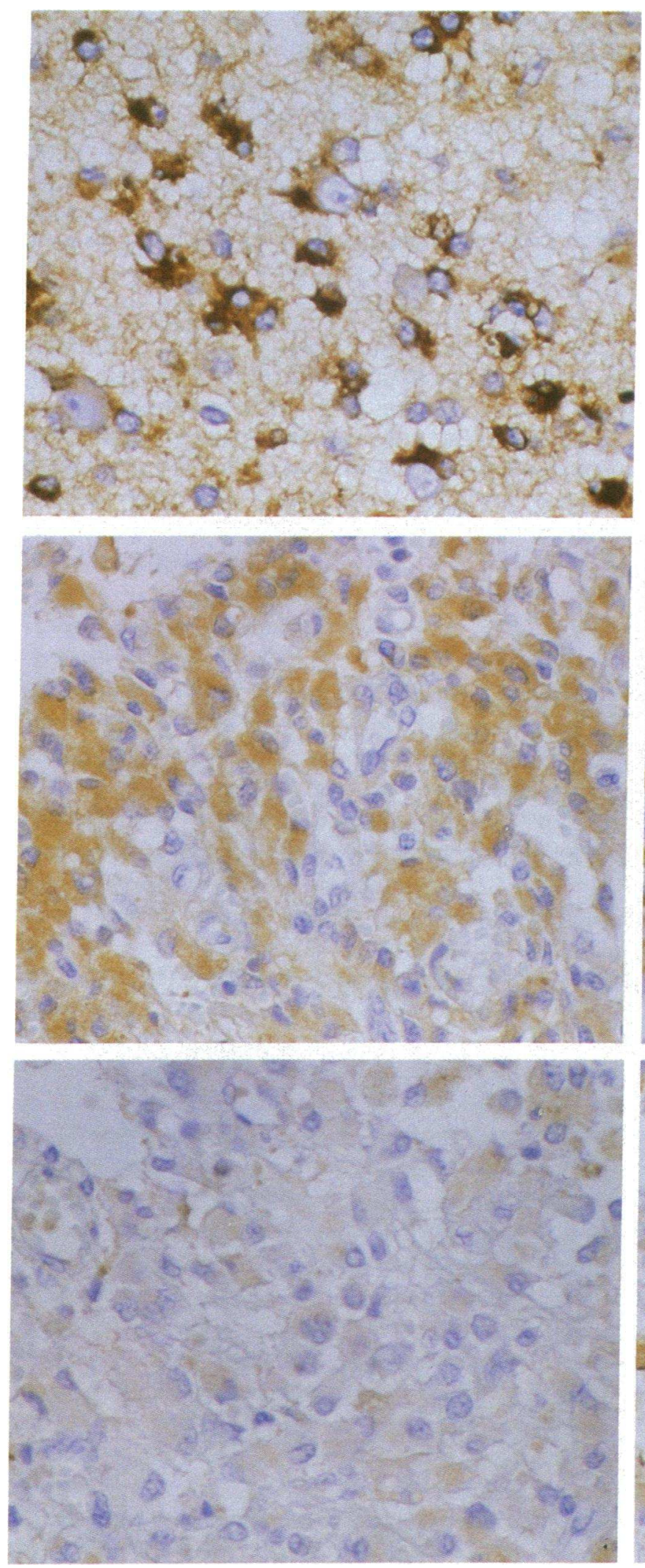

Figure 6. The difference between apo E and GFAP immunorectivity in high grade astrocytoma $(\times 520)$. Perikaryal immunostaining is seen in the tumor cells, with a moderate degree of reaction for apo $\mathrm{E}$ $(A)$ and a strong reaction for GFAP $(B)$ in the same fields of serial
Figure 5. Apo E localization in low grade astrocytoma ( $\times$ 520). Intensely immunoreactive apo $\mathrm{E}$ is seen around the nucleus of most astrocytoma cells. Light counterstain with hematoxylin.
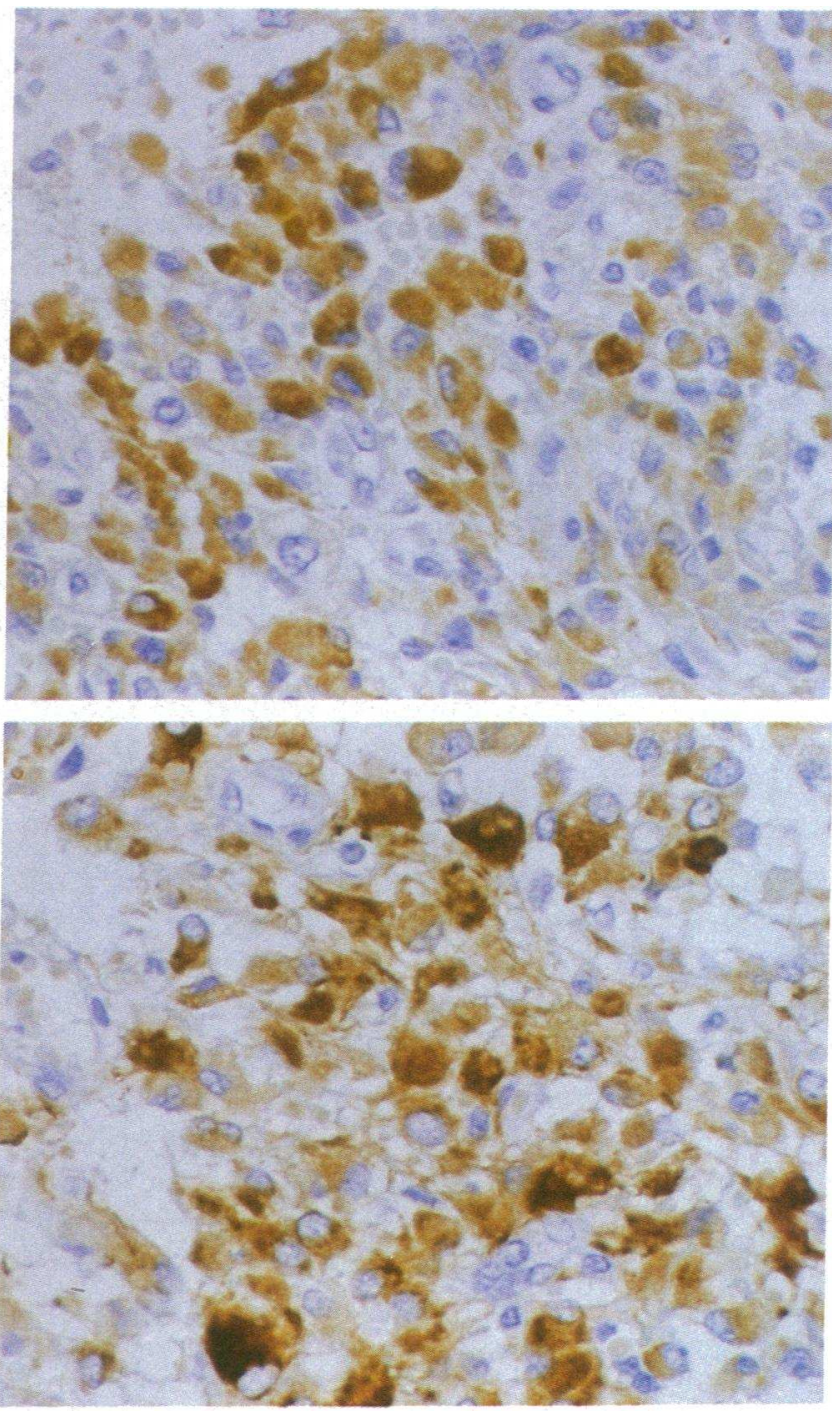

sections. No immunoreaction for apo $\mathrm{E}(C)$ is observed in some areas with a strong immunoreaction for GFAP $(D)$ in the serial sections. Light counterstain with hematoxylin was used. 
Table II. Correlations between Tumor Grading and Apo E or GFAP Immunoreactivity in 18 Astrocytomas

\begin{tabular}{lccc}
\hline & +++ & ++ & + \\
\hline Apo E & & & \\
Grade 1, 2 cases & 1 & 1 & \\
Grade 2, 9 cases & 3 & 4 & 2 \\
Grade 3, 7 cases & & 1 & 6 \\
GFAP & & & \\
Grade 1, 2 cases & 1 & 1 & \\
Grade 2, 9 cases & 4 & 3 & 2 \\
Grade 3, 7 cases & 3 & 4 & \\
\hline
\end{tabular}

A much more negative correlation was observed between tumor grading and immunoreactivity in apo $\mathrm{E}$ than in GFAP. Immunoreactivity is expressed according to the intensity and the number of positive cells, as follows: +++ , strong, more than $60 \% ;++$, moderate, $20-60 \%$; + , weak, less than $20 \%$; -, negative, $0 \%$. specific anti-apo $E$ antibody at 1:3,000. In addition, the most appropriate dilution of the monospecific anti-apo $\mathrm{E}$ antibody to use was $1: 60,000$, thereby indicating that apo $\mathrm{E}$ is fixation sensitive (data not shown).

Secretion of apo E from cultured glioma cells. To investigate whether apo E was secreted from the astrocytic tumor cells into the cultured medium, the following study was performed (Fig. 12). Upon primary culture of the low grade astrocytoma, a significant amount of apo $\mathrm{E}$ was detected at the basal value in medium. The secretion of apo $\mathrm{E}$ from the cells was enhanced $1.8-2.0$-fold by $\beta$-methasone, db-cAMP, or LDL. The mechanism is unknown. In contrast, no apo $\mathrm{E}$ secretion was observed with the glioblastoma cell line (KMG-5), even in the presence of various agents. In addition, the immunofluorescence study using cultured cells indicated that the primary culture of the astrocytoma contained $\sim 80 \%$ GFAP positive cells and the cell line contained $\sim 5 \%$ or less (data not shown). To examine whether apo $\mathrm{E}$ detected in the medium is due to tumor cell destruction, we measured lactate dehydrogenase activity of the culture medium. The lack of lactate dehy-

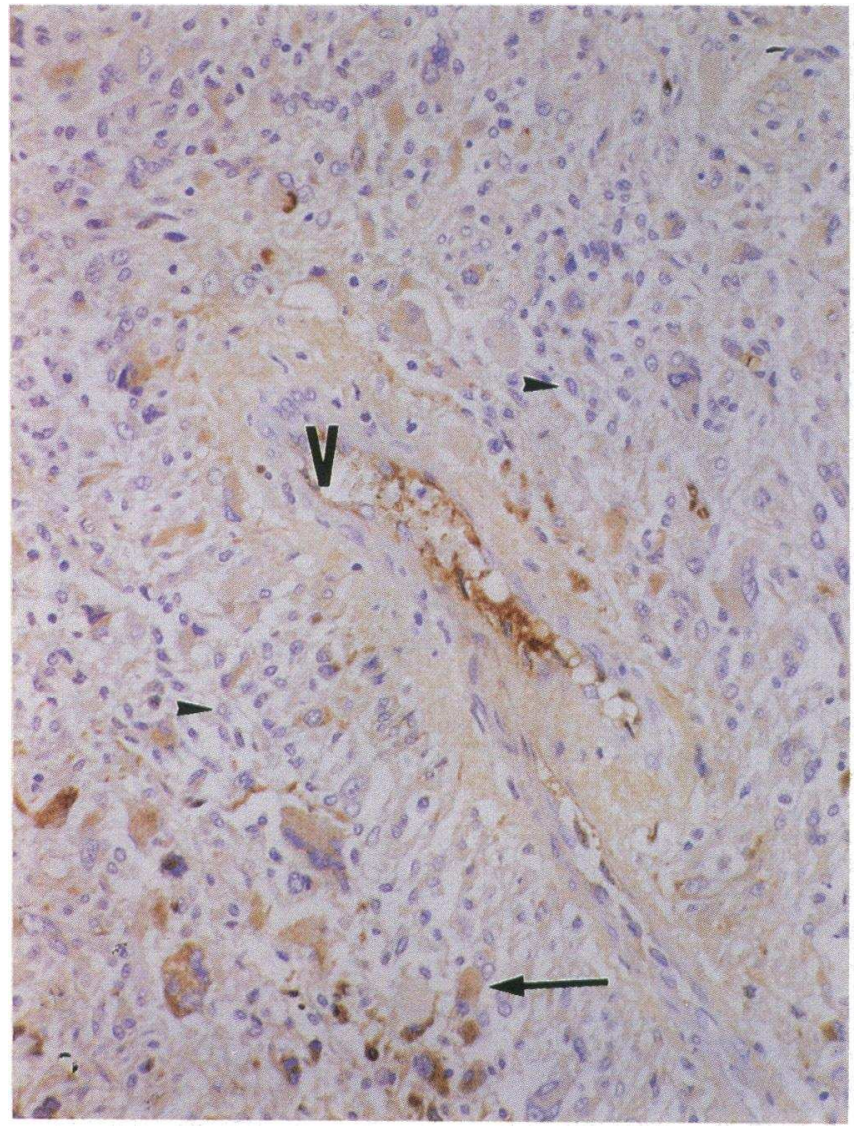

Figure 7. The difference between apo E and GFAP immunoreactivity in glioblastoma. In case $1(A$ and $B)$, the cells with a gemistocytic or bizarre form (arrow) are moderately to intensely reacted for apo $\mathrm{E}$ and the cells with large and multinucleated forms are weakly reacted for apo E, and the small, round components show very little or no immunostaining for apo $\mathrm{E}$ (arrowheads). In addition, serum components within the blood vessel $(V)$ show a strong reaction for apo $\mathrm{E}$ $(A, \times 260)$. In contrast, a higher GFAP immunoreactivity is detected in several varieties of the cells in the same field as $A$ in serial sections

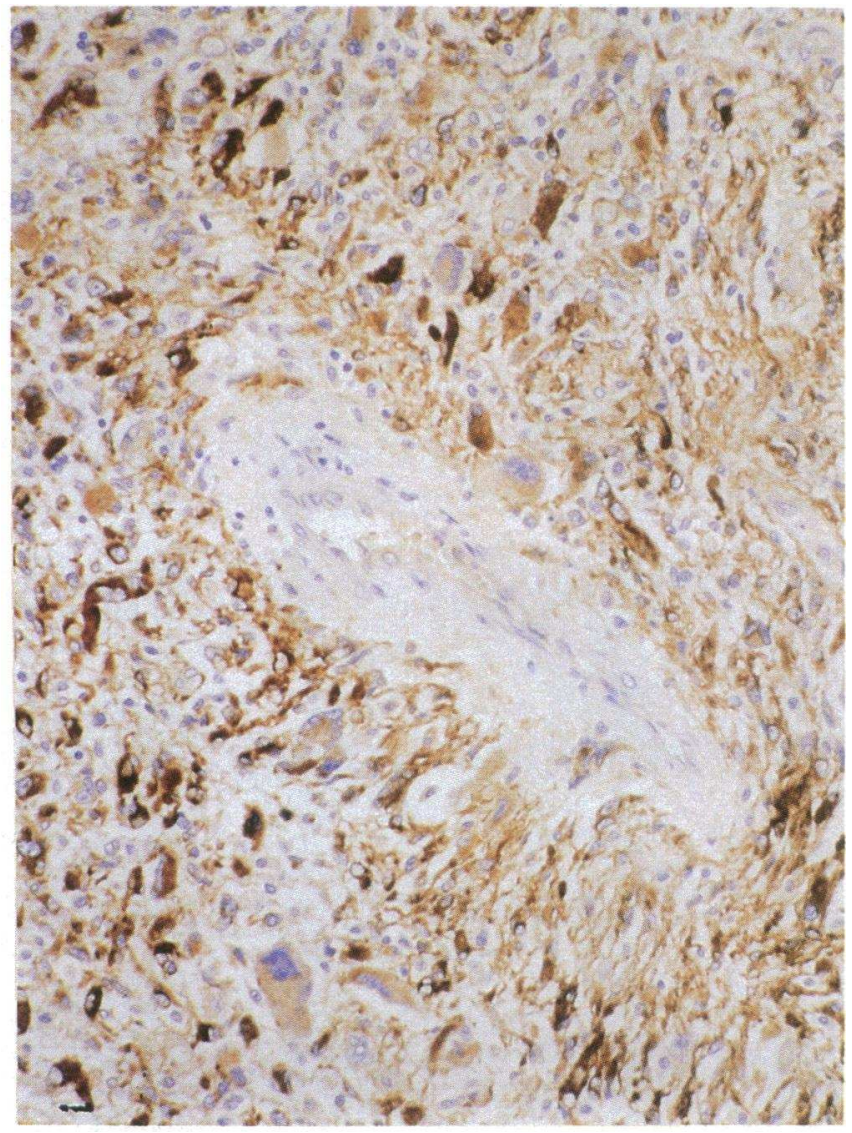

$(B, \times 260)$. In case $2(C-E)$, only a few of the tumor cells show moderate immunoreaction for apo $\mathrm{E}$ (arrowhead), although serum components within the blood vessel $(V)$ demonstrate a strong reaction for apo $\mathrm{E}(C, \times 420)$. In contrast, a high number of the tumor cells especially in the perivascular areas reveal GFAP immunoreaction to a moderate degree $(D, \times 520)$. None of the cells are stained positively using human macrophage-specific antibody $(E, \times 520)$. Light counterstain with hematoxylin was used. 

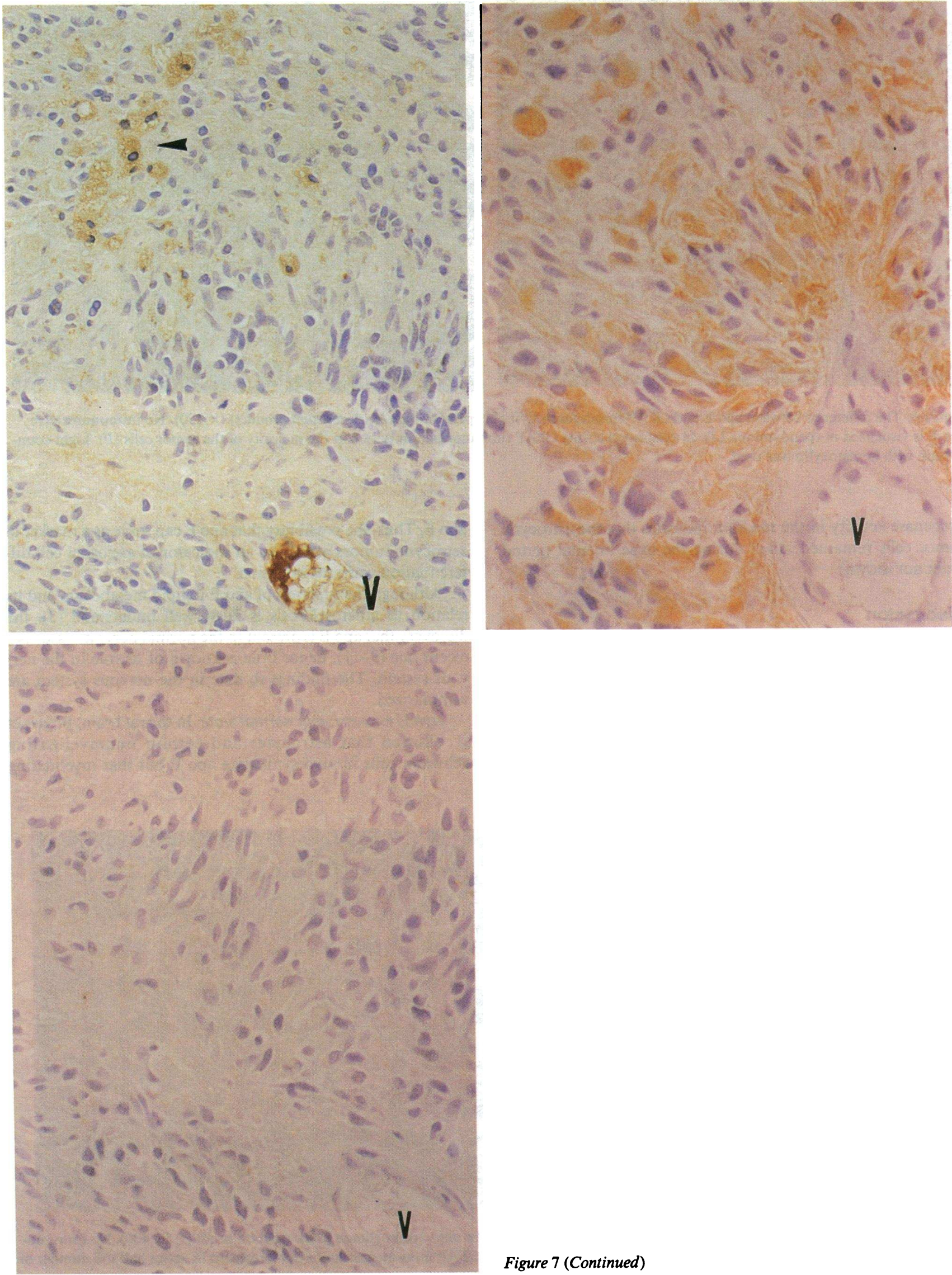

Figure 7 (Continued) 

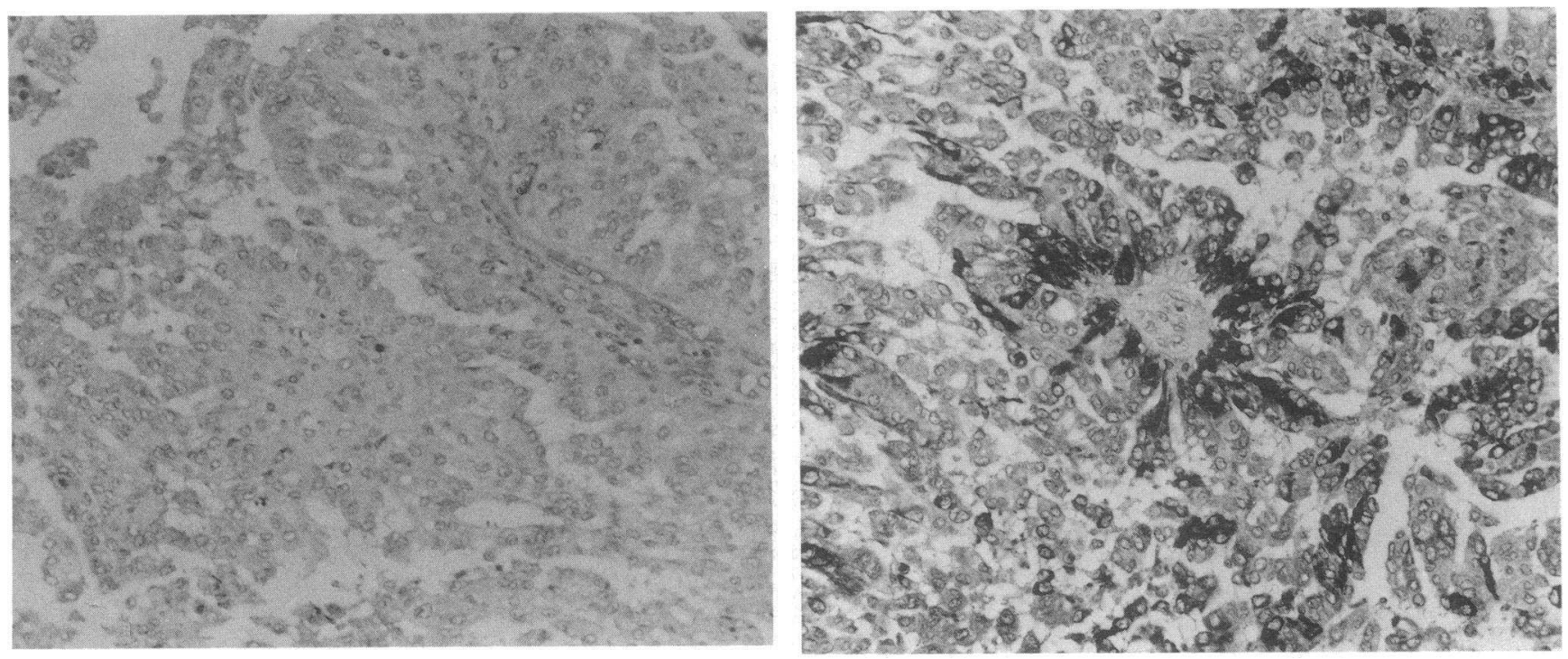

Figure 8 . The difference between apo E and GFAP immunoreactivity in ependymoma (dark reaction product) $(\times 150)$. No immunoreactive apo $\mathrm{E}$ is visualized in ependymoma $(A)$. In contrast, a strong GFAP immunoreaction is seen in the majority of the tumor cells $(B)$. Light counterstain with hematoxylin was used.

drogenase activity in the medium indicates that the astrocytic tumor cells remained intact during the experimental period (data not shown).

\section{Discussion}

We obtained evidence that all types of astrocytomas and glioblastomas exhibit an immunoreaction for apo $\mathrm{E}$, with a negative correlation between the intensity of immunoreactivity and the degree of anaplasia. The astrocytic elements are stained in the case of the medulloblastoma with glial differentiation. In addition, well differentiated cultured astrocytoma cells secrete apo E. Thus, the possibility that apo E can serve as a marker of astrocytic tumors as well as an indicator of astroglial cell differentiation warrants attention.

Although the function of apo $\mathrm{E}$ in lipid metabolism and its relation to atherosclerosis is fairly well understood (3), the discovery that apo $\mathrm{E}$ is present in the normal nervous tissue is a recent one (9-11), hence little is known of its role in the nervous system. The findings to date in the nervous system are summarized.

Apo E expression in normal state. In the rat brain, Boyles et al. showed that astrocytes and certain nonmyelinating Schwann cells in vivo synthesize apo $\mathrm{E}$ but that myelinating
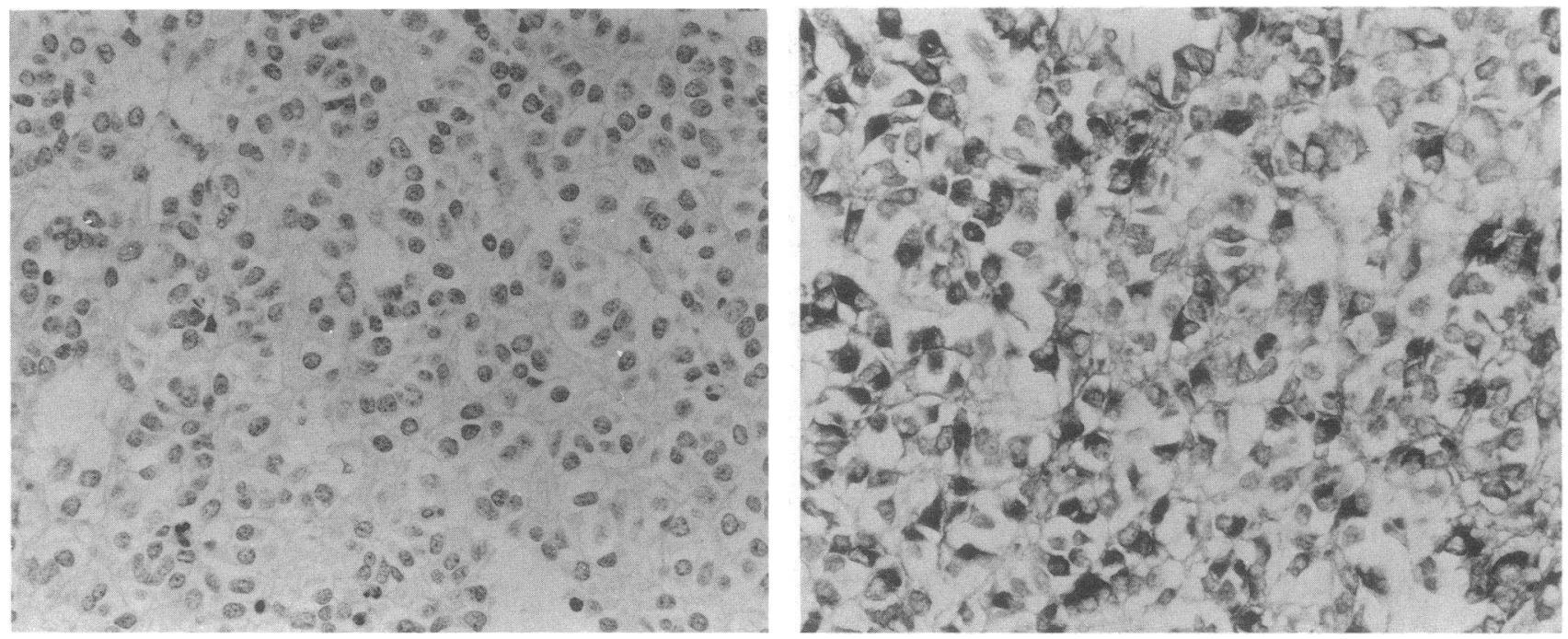

Figure 9. The difference between apo E and GFAP immunoreactivity in the oligodendroglioma (dark reaction product) $(\times 400)$. No immunoreactive apo $\mathrm{E}$ is observed in oligodendroglioma $(A)$. In contrast, a strong GFAP immunoreaction is demonstrated in about half the number of tumor cells $(B)$. Light counterstain with hematoxylin was used. 

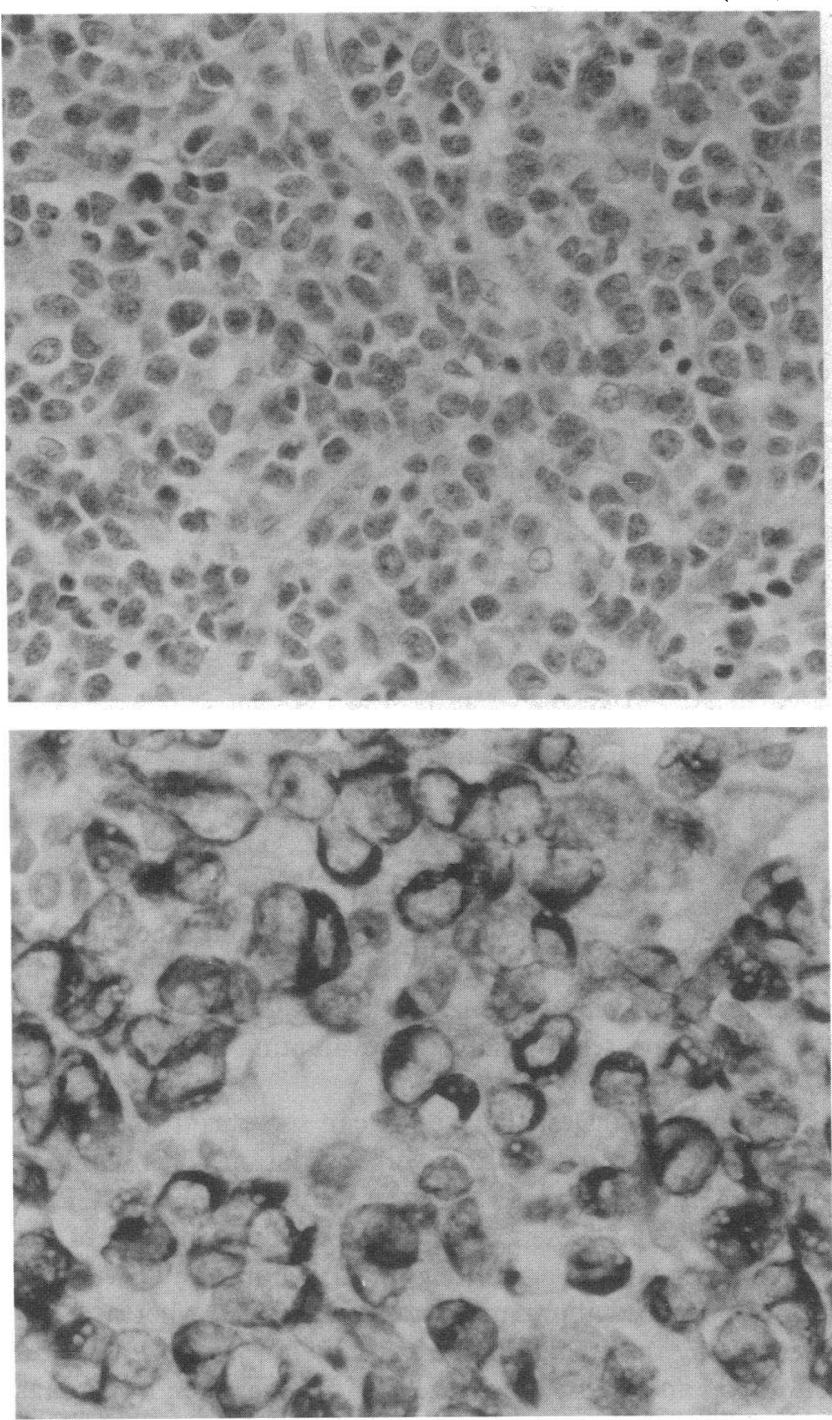

Schwann cells and oligodendrocytes do not produce this protein (11).

Apo $E$ expression in nerve injury. After peripheral nerve injury, apo $\mathrm{E}$ was found to be significantly increased in the degenerating portion of the nerve (29-33). Invading macrophages are the major source of this protein (33). After central nerve injury, apo $\mathrm{E}$ was found to increase in the brain tissue (32). However, macrophages apparently did not play the dominant role at the onset of degenerative events, rather reactive astrocytes appeared to contribute to the total amount of the protein in the damaged nerve early in the history of the lesion, with macrophages contributing significantly only some weeks later (33).

Apo $E$ expression in neoplasms. Apo $\mathrm{E}$ was found to be synthesized by human neurofibrosarcoma-derived cell culture, but not by cells from benign neurofibroma (12). However, these cases are rare and the authors did not clearly establish that immunocytochemical localization of apo $E$ is a useful approach for identification or staging of human glial neoplasms.

The present study focuses on the usefulness of apo E for diagnosis. Our results indicate that apo E localization in

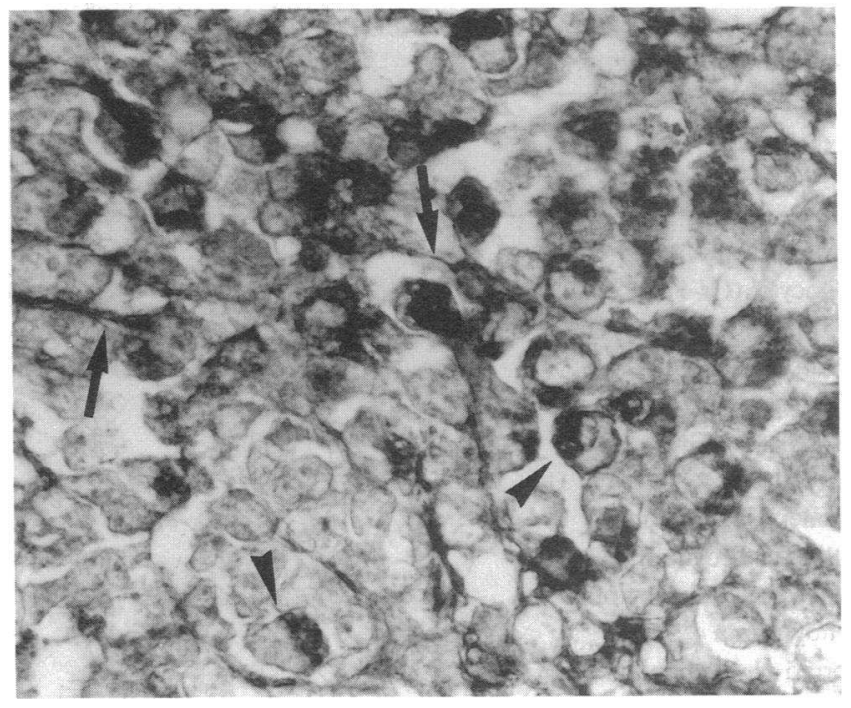

Figure 10. Apo E and GFAP localization in medulloblastoma. Small, round to polygonal cells with highly hematoxyphilic nuclei and no special arrangement are evident. No distinct processes are recognized $(A$, hematoxylin-eosin staining, $\times 320)$. Strong positive staining for apo $\mathrm{E}$ is seen in the perikarya (arrowheads) and polar processes (arrows) as well $(B, \times 800)$. In the same fields as $B$ in serial sections, the cells simultaneously express a strong GFAP immunoreaction in the perikarya $(C, \times 800)$. Light counterstain with hematoxylin was used.

human brain tumors may be clinically relevant and diagnostically useful.

As macrophages are present in some neoplasms, and secrete copious quantities of apo E (34), the question arises as to whether apo E-reactive macrophages are present in the specimen used. To ascertain this critical point, human macrophage-specific antibody (28) was used for cell identification. The finding that none of the cells were stained positively in case 2 of glioblastoma would argue against the apo E-reactive cells being macrophages (Fig. 7).

The apo E reactivity identified in neoplastic astrocytic cells appears to be synthesized by these cells. The possibility that apo $\mathrm{E}$ from the plasma enters these tumors where the bloodbrain barrier no longer exists can be ruled out. If such were true, most apo $\mathrm{E}$ immunoreactive cells would be expected to be found in regions closest to the blood vessels. This is not the case. Preliminary electron microscopic immunohistochemical investigations have shown that apo $\mathrm{E}$ is present in the Golgi apparatus of astrocytoma cells (unpublished observation). In addition, the apparently higher molecular mass of apo $\mathrm{E}$ from tissue extracts of a human glioma $(\sim 37,000 \mathrm{D})$, compared with $34,000 \mathrm{D}$ for plasma apo $\mathrm{E}$, would argue against the point 
Table III. Immunocytochemical Demonstration of Apo E in Human Brain Tumors

\begin{tabular}{|c|c|c|c|}
\hline \multirow[b]{2}{*}{ Tumor type } & \multirow[b]{2}{*}{ Total } & \multicolumn{2}{|c|}{ Positive } \\
\hline & & Apo E & GFAP \\
\hline \multicolumn{4}{|l|}{ Astrocytic tumor } \\
\hline Pilocytic (Gr-1) & 2 & 2 & 2 \\
\hline Fibrillary (Gr-2) & 2 & 2 & 2 \\
\hline Protoplasmic (Gr-2) & 5 & 5 & 5 \\
\hline Gemistocytic (Gr-2) & 2 & 2 & 2 \\
\hline Anaplastic (Gr-3) & 7 & 7 & 7 \\
\hline Glioblastoma (Gr-4) & 9 & 9 & 9 \\
\hline \multicolumn{4}{|l|}{ Oligodendroglial tumor } \\
\hline Oligodendroglioma & 3 & 0 & 3 \\
\hline Mixed oligoastrocytoma & 2 & $2 * 1$ & $2 * 2$ \\
\hline Ependymoma & 10 & 2 & 10 \\
\hline Choroid plexus papilloma & 2 & 0 & 0 \\
\hline Medulloblastoma & 12 & 3 & 2 \\
\hline Neuroblastoma (peripheral) & 5 & 0 & 0 \\
\hline Hemangioblastoma & 3 & 0 & 0 \\
\hline Malignant lymphoma (primary) & 2 & 0 & 0 \\
\hline Neurinoma & 5 & 0 & 0 \\
\hline Meningioma & 2 & 0 & 0 \\
\hline Pituitary adenoma & 2 & 0 & 0 \\
\hline Craniopharyngioma & 2 & 0 & 0 \\
\hline Total & 77 & & \\
\hline
\end{tabular}

All cases of astrocytomas and glioblastomas that were examined exhibited a positive immunoreaction for apo E. Only 2 of 10 ependymomas examined exhibited an immunoreaction for apo E. Only 3 of 12 medulloblastomas examined exhibited an immunoreaction for apo E. In contrast, all 10 ependymomas and only 2 of 12 medulloblastomas showed immunoreaction for GFAP. No immunoreaction for apo $\mathrm{E}$ was seen in oligodendrogliomas, choroid plexus papillomas, neuroblastomas, hemangioblastomas, primary malignant lymphomas, neurinomas, meningiomas, pituitary adenomas, and craniopharyngiomas. * 1 shows that only astrocytic components of mixed gliomas revealed an apo $\mathrm{E}$ immunoreaction and *2 shows that both components in one case and only astrocytic components in the other were stained for GFAP.

that apo $\mathrm{E}$ is of plasma origin. This apparently higher molecular weight may be due to sialylation (35) and has been reported previously for brain and neural tissue apo E (11, 29-33).

Antibodies to GFAP are apparently not species-specific $(36,37)$. Our anti-human apo E antibody, however, did not react with either bovine (Fig. 1) or rat serum apo $E$ (data not shown), thereby indicating that the antigenic determinants for apo $\mathrm{E}$ differ between these species.

It has been established that GFAP is localized in astrocytes and in Bergmann radial glia of cerebellum, but not in other nervous tissue cells such as neurons, oligodendrocytes, ependymal cells, and choroidal epithelium $(26,38)$. Furthermore, it is generally accepted that GFAP is present in glioma with a negative correlation to the degree of anaplasia, hence indicating that GFAP is a marker of glial cell tumors $(23,27)$. Several investigators (39-43) using immunocytochemical techniques have demonstrated that in ependymal and oligodendroglial tumors a high number of GFAP-positive neoplastic elements

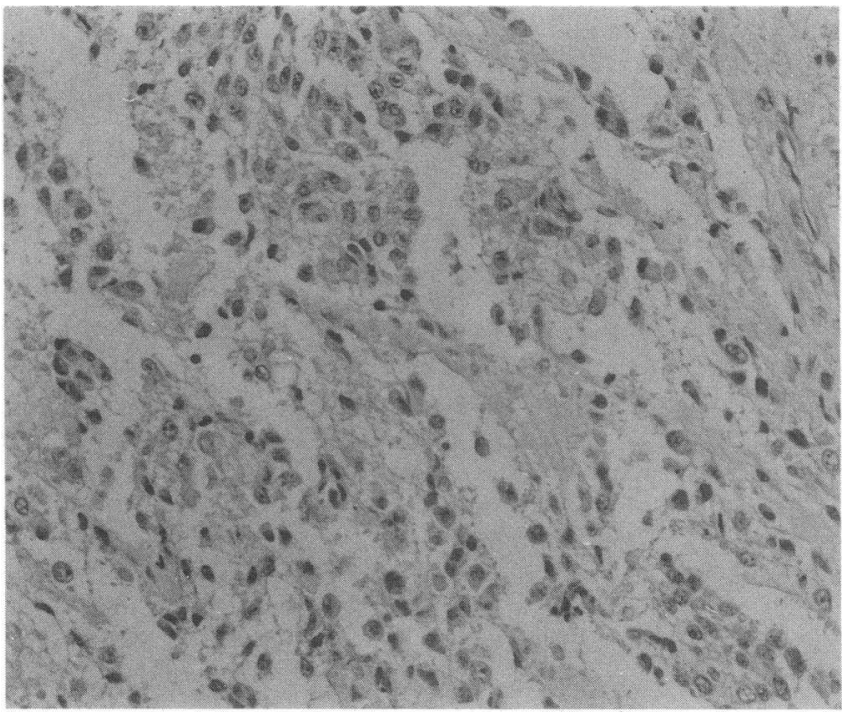

Figure 11. Apo E immunoreactivity in neuroblastoma $(\times 230) \mathrm{Im}-$ munoreaction for apo $\mathrm{E}$ is nil.

are detected and a high GFAP content can be detected even in malignant glioma as well as in low grade glioma. They seemed to favor the view that GFAP is not an astrocyte-specific but rather a glial-specific protein, and that a GFAP investigation does not always seem reliable for evaluating undifferentiated tumors.

Our results suggest that apo E can serve as a marker for astroglial cell tumors and their differentiation. This seems to be in general agreement with the results obtained by GFAP localization. The present study demonstrated that all of the cases of ependymomas and oligodendrogliomas that were examined possessed abundant amounts of GFAP, whereas a few cases among the ependymomas exhibited a weak immunoreaction for apo $\mathrm{E}$, and no cases among oligodendrogliomas showed a reaction product for apo $\mathrm{E}$. Second, on examination of anaplastic astrocytomas and glioblastomas, the GFAP immunoreaction is much more intense than the apo $\mathrm{E}$ immunoreaction. Our results, therefore, suggest that apo $\mathrm{E}$, more that GFAP, is a valuable marker of astrocytic tumors as well as an indicator of cell differentiation. Naturally, a combined apo E/GFAP profile of immunoreaction would further aid in the identification and staging of glial neoplasms of the central nervous system. It should, therefore, prove to be a clinically useful antigenic determinant.

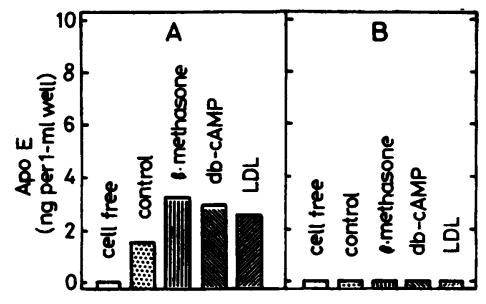

Figure 12. Secretion of apo $\mathrm{E}$ from human cultured glioma cells. Upon primary culture of astrocytoma, apo E secretion is detected at the basal value with 1.8-2.0-fold enhancement by $\beta$-methasone, db-cAMP, or LDL $(A)$. In contrast, on cell line KMG-5 $(B)$ no db apo $E$ secretion is observed even in the presence of the agents described above. All the data obtained are from duplicate experiments. 


\section{Acknowledgments}

This work was supported in part by a Grant-in-Aid for Scientific Research from the Ministry of Education, Science, and Culture of Japan.

We are grateful to Dr. S. Horiuchi, Dr. Y. Mihara, and Dr. S. Fukuda for valuable discussions and suggestions, to Ms. Y. Sonoda for excellent technical service and to M. Ohara for editorial assistance.

\section{References}

1. Rall, S. C., Jr., K. H. Weisgraber, and R. W. Mahley. 1982. Human apolipoprotein E: the complete amino acid sequence. J. Biol. Chem. 257:4171-4178.

2. Mahley, R. W., and T. L. Innerarity. 1983. Lipoprotein receptors and cholesterol homeostasis. Biochim. Biophys. Acta. 737:197-222.

3. Mahley, R. W., T. L. Innerarity, S. C. Rall, Jr., and K. H. Weisgraber. 1984. Plasma lipoproteins: apolipoprotein structure and function. J. Lipid Res. 25:1277-1294.

4. Pitas, E., T. L. Innerarity, K. S. Arnold, and R. W. Mahley. 1981. Rate and equilibrium constants for binding of apo-E HDLc (a cholesterol-induced lipoprotein) and low density lipoproteins to human fibroblasts. Evidence for multiple receptor binding of apo-E HDLc. Proc. Natl. Acad. Sci. USA 76:2311-2315.

5. Hui, D. Y., T. L. Innerarity, and R. W. Mahley. 1981. Lipoprotein binding to canine hepatic membrane. J. Biol. Chem. 256:56465655.

6. Carrela, M., and A. D. Cooper. 1979. High affinity binding of chylomicron remnants to rat liver plasma membranes. Proc. Natl. Acad. Sci. USA. 76:338-342.

7. Williams, D. L., P. A. Dawson, T. C. Newman, and L. L. Rudel. 1985. Apolipoprotein E synthesis in peripheral tissues of nonhuman primates. J. Biol. Chem. 260:2444-2451.

8. Blue, M.-L., D. L. Williams, S. Zucker, S. A. Khan, and C. B. Blum. 1983. Apolipoprotein E synthesis in human kidney, adrenal, and liver. Proc. Natl. Acad. Sci. USA. 80:283-287.

9. Elshourbagy, N. A., W. S. Liano, R. W. Mahley, and J. M. Taylor. 1984. Apolipoprotein E mRNA is abundant in the brain and adrenals, as well as in the liver, and is present in other peripheral tissues of rats and marmosets. Proc. Natl. Acad. Sci. USA. 82:203-207.

10. Roheim, P. S., M. Carey, T. Forte, and G. L. Vega. 1979. Apolipoproteins in human cerebrospinal fluid. Proc. Natl. Acad. Sci. USA. 76:4646-4649.

11. Boyles, J. K., R. E. Pitas, E. Wilson, R. W. Mahley, and J. M. Taylor. 1985. Apolipoprotein E associated with astrocytic glia of the central nervous system and with nonmyelinating glia of the peripheral nervous system. J. Clin. Invest. 76:1501-1513.

12. Gebicke-Haerter, P. J., J. K. Darby, E. M. Shooter, V. M. Riccardi, K. H. Weisgraber, J. K. Boyles, and R. W. Mahley. 1987. Apolipoprotein E synthesis in neurofibrosarcoma and Schwannoma cell cultures from two individuals with neurofibromatosis. Exp. Neurol. 95:323-335.

13. Shelburne, F. A., and S. H. Quarfordt. 1977. The interaction of heparin with an apoprotein of human very low density lipoprotein. $J$. Clin. Invest. 60:944-950.

14. Murakami, M., S. Horiuchi, K. Takata, and Y. Morino. 1986. Scavenger receptor for malondialdehyde-modified high density lipoprotein on rat sinusoidal liver cells. Biochem. Biophy. Res. Commun. 137:29-35.

15. Murakami, M., S. Horiuchi, K. Takata, and Y. Morino. 1987. Distinction in the mode of receptor-mediated endocytosis between high density lipoprotein and acetylated high density lipoprotein: evidence for high density lipoprotein receptor-mediated cholesterol transfer. J. Biochem. (Tokyo). 101:729-741.

16. Horiuchi, S., K. Takata, and Y. Morino. 1985. Characterization of a membrane-associated receptor from rat sinusoidal liver cells that binds formaldehyde-treated serum albumin. J. Biol. Chem. 260:475-481.

17. Horiuchi, S., M. Murakami, K. Takata, and Y. Morino. 1986. Scavenger receptor for aldehyde-modified proteins. J. Biol. Chem. 261:4962-4966.

18. Ohta, T., N. H. Fidge, and P. J. Nestel. 1985. Studies on the in vivo and in vitro distribution of apolipoprotein A-4 in human plasma and lymph. J. Clin. Invest. 76:1252-1260.

19. Yoshitake, S., M. Imagawa, and E. Ishikawa. 1982. Mild and efficient conjugation of rabbit $\mathrm{Fab}^{\prime}$ and horseradish peroxidase using a maleimide compound and its use for enzyme immunoassay. J. Biochem. (Tokyo). 92:1413-1424.

20. Fukuda, S., S. Horiuchi, K. Tomita, M. Murakami, Y. Morino, and K. Takahashi. 1986. Acetylated low-density lipoprotein is endocytosed through coated pits by rat peritoneal macrophages. Virchows Arch. B Cell Pathol. 52:1-13.

21. Kyhse-Andersen, J. 1984. Electroblotting of multiple gels; a simple apparatus without buffer tank for rapid transfer of proteins from polyacrylamide to nitrocellulose. J. Biochem. Biophys. Methods. 10:203-209.

22. Mihara, Y. 1986. Establishment and characterization of 5 cell lines derived from human brain tumors. Kumamoto Med. J. 39:25-41.

23. Eng, L. F., and S. J. DeArmond. 1983. Immunochemistry of the glial fibrillary acidic protein. Prog. Neuropathol. 5:19-39.

24. Salm, A. K., G. I. Hatton, and G. Nilaver. 1982. Immunoreactive glial fibrillary acidic protein in pituicytes of the rat neurohypophysis. Brain Res. 236:471-476.

25. Basco, E., P. L. Woodhams, F. Hajos, and R. Balazs. 1981. Immunocytochemical demonstration of glial fibrillary acidic protein in mouse tanycytes. Anat. Embryol. 162:217-222.

26. Bignami, A., L. F. Eng, D. Dahl, and C. T. Uyeda. 1972. Localization of the glial fibrillary acidic protein in astrocytes by immunofluorescence. Brain Res. 43:429-435.

27. Velasco, M. E., D. Dahl, U. Roessmann, and P. Gambetti. 1980. Immunohistochemical localization of glial fibrillary acidic protein in human glial neoplasms. Cancer. 45:484-494.

28. Brooks, D. A., H. Zola, P. J. McNamara, J. Bradley, K. F. Bradstock, W. W. Hancock, and R. C. Atkins. 1983. Membrane antigens of human cells of the monocyte/macrophage lineage studied with monoclonal antibodies. Pathology. 15:45-52.

29. Muller, H. W., M. J. Ignatius, D. H. Hangen, and E. M. Shooter. 1986. Expression of specific sheath cell proteins during peripheral nerve growth and regeneration in mammals. J. Cell Biol. 102:393-402.

30. Snipes, G. J., C. B. McGuire, J. J. Norden, and J. A. Freeman. 1986. Nerve injury stimulates the secretion of apolipoprotein $\mathrm{E}$ by nonneuronal cells. Proc. Natl. Acad. Sci. USA. 83:1130-1134.

31. Ignatius, M. J., P. J. Gebicke-Harter, J. H. Pate Skene, J. W. Schilling, K. H. Weisgraber, R. W. Mahley, and E. M. Shooter. 1986. Expression of apolipoprotein $\mathrm{E}$ during degeneration and regeneration. Proc. Natl. Acad. Sci. USA. 83:1125-1129.

32. Muller, H. W., P. J. Gebicke-Haerter, D. H. Hangen, and E. M. Shooter. 1985. A specific 37,000-Dalton protein that accumulates in regenerating but not in nonregenerating mammatian nerves. Science (Wash. DC). 228:499-501.

33. Boyles, J. K., R. E. Pitas, K. H. Weisgraber, R. W. Mahley, P. J. Gebicke-Haerter, M. J. Ignatius, and E. M. Shooter. 1986. Role for apolipoproteins-E and A-1 in nerve degeneration and regeneration. Arteriosclerosis 6:563A. (Abstr.)

34. Basu, S. K., Y. K. Ho, M. S. Brown, D. W. Bilheimer, R. G. W. Anderson, and J. L. Goldstein. 1982. Biochemical and genetics studies of the apoprotein E secreted by mouse macrophages and human monocytes. J. Biol. Chem. 257:9788-9795.

35. Zannis, V. I., J. Mcpherson, G. Goldberger, S. K. Karathanasis, and J. L. Breslow. 1984. Synthesis, intracellular processing, and signal peptide of human apolipoprotein E. J. Biol. Chem. 259:5495-5499. 
36. Albrechtsen, M., A. C. von Gerstenberg, and E. Bock. 1984. Mouse monoclonal antibodies reacting with human brain glial fibrillary acidic protein. J. Neurochem. 42:86-93.

37. Courel, M.-N., N. Girard, B. Delpech, and C. Chauzy. 1986. Specific monoclonal antibodies to glial fibrillary acidic protein (GFAP). J. Neuroimmunol. 11:271-276.

38. Ludwin, S. K., J. C. Kosek, and L. F. Eng. 1976. The topographical distribution of S-100 and GFA proteins in the adult rat brain: an immunohistochemical study using horseradish peroxidase-labeled antibodies. J. Comp. Neurol. 165:197-208.

39. DeArmond S. J., L. F. Eng, and L. J. Rubinstein. 1980. The application of glial fibrillary acidic protein immunohistochemistry in neurooncology. Pathol. Res. Pract. 168:374-394.
40. Ishida, Y., K. Takahashi, and Y. Nakazato. 1982. Immunohistochemical and electron-microscopic studies of experimental and human oligodendrogliomas. 11th Int. Congr. Neuropathol. Vienna, Sept. 181. (Abstr.)

41. Herpers, M. J. H. M., and H. Budka. 1984. Glial fibrillary acidic protein (GFAP) in oligodendroglial tumors: gliofibrillary oligodendroglioma and transitional oligodendrocytoma as subtypes of oligodendroglioma. Acta Neuropathol. 64:265-272.

42. Wilkinson, I. M. S., J. R. Anderson, and A. E. Holmes. 1987. Oligodendroglioma: an andlysis of 42 cases. J. Neurol. Neurosurg. Psychiatry. 50:304-312.

43. Gullotta, F., F. Schindler, R. Schmutzler, and A. Weeks-Seifert. 1985. GFAP in brain tumor diagnosis: possibilities and limitations. Pathol. Res. Pract. 180:54-60. 